\title{
The Effects of Motivation on Staff Job Performance: Evidences from the Lagos State Ministry of Environment, Nigeria
}

\author{
Christiana O. Ogbogu ${ }^{1}$ \\ ${ }^{1}$ Department of Public Administration, Faculty of Administration, Obafemi Awolowo University, Ile-Ife, Osun \\ State, Nigeria \\ Correspondence: Christiana O. Ogbogu, Department of Public Administration, Faculty of Administration, \\ Obafemi Awolowo University, Ile-Ife, Osun State, Nigeria. E-mail: tinaogbogu@yahoo.com; \\ cogbogu@oauife.edu.ng
}

Received: January 4, 2017

doi:10.5539/jsd.v10n2p183
Accepted: March 9, $2017 \quad$ Online Published: March 30, 2017

URL: https://doi.org/10.5539/jsd.v10n2p183

\begin{abstract}
This study examined the effects of motivation on the job performance of staff of the Lagos State Ministry of Environment, Nigeria. It identified the factors that motivate the staff to perform their jobs better and situated those preferred functional and novel strategies that enable them function more efficiently and effectively. The survey research design was adopted for the study and it obtained its data from both primary and secondary sources. The stratified random sampling technic was utilized in administering 140 copies of the questionnaire on both the project and tenured staff of the Lagos State Ministry of Environment, therefore cutting across the rank and file of the Ministry. The retrieved data were analyzed using descriptive statistics in the form of simple percentages. The study found that: regular payment of salary and provision of welfare packages $(51.4 \%)$, conducive working environment $(49.3 \%)$, opportunity for autonomy, creativity and innovative thinking which the job provides $(48.6 \%)$ and the regular training which they are exposed to $(45 \%)$ motivated them to perform their jobs better. Results of the analysis further revealed that the motivational strategies preferred by the staff and which would make them more efficient and effective include: ensuring that the project staff attain tenure (55.7\%), recognizing and rewarding outstanding performance $(54.3 \%)$ making the existing retirement plan more reliable $(53.6 \%)$ provision of modern working facilities $(52.1 \%)$, increase in salary with welfare packages and bonuses $(52.9 \%)$, amongst others. The study concluded that motivation is pivotal for enhancing staff job performance and a driving force for the overall efficiency of an organization. Hence, there should be diversity in the motivation techniques adopted to meet the needs of the staff as well as the changes in the work environment.
\end{abstract}

Keywords: motivation, staff job performance, Ministry of Environment, Lagos

\section{Introduction}

The success of an organization depends on how well motivated its workers are as well as the extent to which the leaders are equipped with the skills and knowledge of motivation. Motivation is a factor which affects the job performance of staff as well as the overall efficiency of an organization. It is therefore concerned with factors that influence people to behave in a certain way to get them to achieve results.

Motivation is seen by many scholars (Herzberg, Mausner \& Snyderman 1959; Maslow, 1970 \& Armstrong, 2006) as a goal directed behaviour which enhances the job performance of workers. They affirm that well motivated workers perform maximally. This implies that people are motivated when a valued reward which satisfies their needs is attached. Employee motivation is therefore important to job performance and organizational well-being. This is why individuals with less natural talent or professional expertise can sometimes outperform their more gifted colleagues if adequately motivated (Mitchell, 1982). It is important not just to hire capable individuals but also to use strategies to inspire them to do their best. This is because; it has been found that well motivated individuals have direction and persistence of action even in the face of difficulties and challenges (Armstrong, 2006).Motivation has overtime become a major factor for influencing the productivity of workers in organisations (Evans, 1999). Organisations should therefore provide the context within which high levels of motivation can be achieved by providing incentives, rewards satisfying work environment, and opportunities for learning and growth.Importantly, managers have a major part to play in using their motivating skills to get people to give of their best and to make good use of the motivational processes provided by the organization. 
Organizations should be concerned with what should be done to achieve sustained high level of performance through people. This means giving close attention to how individuals can best be motivated through such means as incentives, rewards, leadership, the work they do and the organizational context within which they can carry out that work. The focus is to develop motivation processes and a work environment that help to ensure that individuals deliver results in accordance with the expectations of management (Bloisi, 2007).

Consequently managers are continually challenged to motivate the workforce to first help organization achieve its goals and secondly to motivate workers towards achieving their own personal goals. It is important to note that if employees are not motivated and satisfied with their jobs, they will not function effectively to achieve organizational goals. This is usually a difficult task for managers; they therefore need the skills as well as understand the applicable ways to transfer concepts of motivation to everyday work life and practice.

The Nigerian public sector over the years has not successfully motivated her staff and this has given rise to intermitted strikes and industrial actions. The sector is noted for overstaffing, poor work environment and facilities, as well as poor remuneration, just to mention a few. These factors are regarded as germane to their poor performance. This study became expedient due to the abysmal performance and low level of productivity of staff of public organizations and agencies in Nigeria. The study therefore sought to examine the motivational strategies available in the Lagos State Ministry of Environment and also sought to situate those preferred functional and novel strategies that motivate employees to function more efficiently and effectively.

\section{Literature Review and Theoretical Framework}

Motivation is a broad concept that is concerned with the factors that influence people to behave in certain ways. In support of this, Fielding (2006) affirmed that motivation is the force within a person that makes him or her act in a certain way to achieve some set goals. Scott (2007) defined motivation as the processes that account for individual's intensity, direction and persistence of effort towards attaining a goal. A needs - related model of the process of motivation suggests that motivation is initiated by the conscious or unconscious recognition of unsatisfied needs. Armstrong (2006) noted that most people need to be motivated to a greater degree to perform effectively. Huczynski and Buchanan (2007) argued that motivation is a combination of goals towards which human behaviour is directed, the process through which those goals are pursued and achieved and the social factors involved.They further indicated that the three components of motivation are direction, effort and persistence. Motivation is therefore a concept that is driven by desires and needs which should be satisfied. This being the case, managers must create an enabling environment for workers to be motivated. Those who can motivate employees improve employee retention and reinforce positive behaviour that increases performance. Fielding (2006) added that managers should understand the importance of motivation because their organizations would benefit if employees are enthusiastic about task accomplishment. This can be achieved through the creation of positive organizational climate. Mitchell (1982) noted that the basic requirement for motivating staff include comparative high pay, an equitable payment system, real opportunities for promotion, considerate and participative management, a reasonable degree of social interaction at work, interesting and varied tasks and a high degree of autonomy. When all of these satisfy workers, they will be productive and perform maximally.

Evans (1999) opined that intrinsic and extrinsic motivations are the major types of motivation identified by Herzberg et al. in 1959.According to him Extrinsic motivation consists of tangible rewards or what is given to people such as pay, salary, fringe benefits or promotion to encourage them. Intrinsic motivation is related to self-generated and psychological factors that influence people to behave in a particular way. These include: opportunity to use one's ability at work, challenging work opportunity and being treated fairly.

The theories of motivation are used to understand employees' job performance. Thus approaches to motivation and job performance in this study are underpinned by motivation theory. Maslow's (1970) theory holds that human needs form a hierarchy ranging from the lowest order needs (i.e. Psychological needs) to the highest order needs (i.e. Self-actualization needs).It states that when a lower need is satisfied, the next highest need becomes dominant and the individual's attention is turned to this higher need. The implication is that the highest order needs provide the greatest impetus to motivation. Vroom's expectancy theory of motivation suggests that people are motivated to reach a goal if they think that goal is worthwhile and if there are activities that can help them attain those goals (Mitchell,1982). In Porter and Lawler's model, performance is a function of ability, the perception of task required and effort. Effort is influenced by the value of rewards and the perceived effort-reward probability. Performance accomplishment is in turn related to rewards and satisfaction. Equity theory focuses an individual's subjective judgment about the fairness of the reward received for inputs in comparison with the rewards of others (Luthans, 1992).The instrumentalists' theory states that people work for money and affirm that a person will be motivated to work if rewards are tied directly to his or her performance. 
This theory is based on the principle of reinforcement. This implies that people can be conditioned to act in certain ways if they are rewarded (Armstrong, 2006). Motivation using this approach has been widely adopted and successful. In this paper, emphasis is also laid on content/needs theory which believes that the content of motivation consists of needs which must be met otherwise unsatisfied needs create tension and a state of disequilibrium. Therefore to restore the balance, a goal that will satisfy the need is identified and a behaviour pathway that will lead to the achievement of the goal is selected. Process theory on the other hand places emphasis on forces that affect motivation. It states that motivation and performance are influenced by the perceived link between effort and performance, the perceived link between performance and outcomes and the significance of the outcome to the person. Invariably motivation therefore depends on the likelihood that rewards will follow effort and that reward is worthwhile (Mitchel, 1982). Herzberg et al. (1959) stressed the need to strengthen motivators in order to engender career satisfaction. In the same vein, Dinham and Scott (1998) pointed out that satisfaction and performance are connected to need fulfillment as conceptualized by Maslow (1970) and Alderfer (1972).

Mullins (1996) noted that money in the form of pay is a major motivator because it provides the means to achieve a number of different ends. It is a powerful force because it is linked to the satisfaction of many needs. Fielding (2006) added that money is an important factor in attracting people to organizations and it is one of the factors that will influence their retention and motivate them to perform.

Apart from money, there are varieties of motivational techniques that can be used to improve productivity, reduce workplace stress and increase self-confidence. Bateman and Snell (2004) for instance opined that team-building is a motivational technique that encourages people to work together and builds their capacity to engage in healthy competition. Improving team relationships according to them can result in increased productivity and staff morale as well as create a healthy working environment. Fielding (2006) note that training is a motivational strategy that teaches people how to deconstruct tasks and challenges. It demonstrates to them how to cope in the workplace such that they are not intimidated by their job roles. Mitchell (1982) added that communication through talking to staff regularly and listening to them is a motivational strategy that enhances performance, but which many superiors don't explore in the workplace. According to him, communication is critical because it demonstrates to workers the importance of their feedback for achievement of targets and standards. Furthermore, rewards not only with financial incentives but with offer of increased responsibility or even promotion are effective strategies for enhancing staff performance. According to Scott (2007), giving workers more freedom to participate in decision making and make inputs about work methods and sequence motivates them and makes them more accountable in performing their tasks. Thus, encouraging participation does not only increase productivity but it also enhances their commitments to work goals.

It is therefore evident, that the sustainability and quality of any organization depends not just on the quality, intellectual, creative abilities and commitments of its staff but mostly on motivation. Thus it is vital for staff of public organizations to be adequately motivated to be effective and efficient in the performance of their job assignments in order to achieve organizational goals.

Unfortunately, evidences (Ubeku, 1975; Lawal, 1993; \& Obisi, 1996) have shown that the public sector workers in Nigeria are not adequately motivated. They are occasionally motivated manly through monetary incentives such as salary increment and other allowances. This has been the trend over the years and it has precipitated the numerous industrial strikes in the country. Money therefore seems to be the most obvious sort of extrinsic remuneration used in the Nigeria public sector. This is not unconnected with fact that money provides the carrot their most people want.

In view of this, Lucy and Sheehan (1997) noted that although workers may feel good when they get an increase, but this feeling of euphoria is only transient. Other factors such as working conditions or the quality of leadership may provide the satisfaction they need to work better. Kuskus (2001) argued that although money may be important in motivating people in organisations and which will influence their retention, but badly designed and managed pay systems can demotivate. Perry and Porter (1982) in this regard, emphasized the need for managers in the public sector to utilize a variety of strategies in motivating their staff. For instance, they noted that managers should pay attention to the basic need for recognition. This is because people are more likely to be motivated if they work in an environment in which they are valued for what they are and what they do. Also workers should be given a reasonable degree of autonomy to use their skills, while competencies should be recognized.

Evans (1999) submitted that motivation will be enhanced by leadership which sets the direction, encourages and stimulates achievement by providing support to employees in their effort to reach goals and improve their 
performance generally. This can be achieved by providing guidance and training to develop leadership qualities. Furthermore, facilities and opportunities for learning and training should be provided as well as develop career planning processes. Also reward systems which provide opportunities for both financial and non-financial rewards to recognize achievements should be developed, bearing in mind that financial rewards are not necessarily the appropriate mode of motivation (Glisson \& Durick, 1988).

Getting the best out of the workforce is critical if they are adequately motivated. It should be noted that motivation has direct impact on performance. There is more to motivating the public sector workers in Nigeria than giving them monetary incentives. Since workers appreciate diversity in the motivation strategies applied, the management of public organizations should therefore breakaway from the stereotypical method that has been adopted through the years.

\section{Methodology}

This study adopted the survey research design and used the Lagos State Ministry of Environment as the case study. Both primary and secondary sources were utilized in obtaining data for the study. Primary data was collected by using the stratified random sampling technique in administering 140 copies of the questionnaire on both the project and tenured staff that make up the staff population of the Ministry of Environment. The questionnaire was designed using the five point Likert-scale format of strongly agree to strongly disagree. It consisted of questions that solicited socio-demographic information about the respondents. It also sought to elicit the respondents' opinions on the existing motivational strategies available and utilized in the ministry with a view to determine the extent to which they enhance their job performance. Further still, the questionnaire sought to identify the preferred motivational strategies that can be adopted to enhance staff performance. Due to the nature of the study which is a survey and therefore an opinion study, the retrieved questionnaires were analyzed using descriptive statistics in the form of simple percentages.

\section{Results and Discussion}

Table 1. Distribution of respondents' demographic characteristics

\begin{tabular}{|c|c|c|}
\hline Variables & Frequency & Percentage (\%) \\
\hline \multicolumn{3}{|l|}{ Sex } \\
\hline Male & 80 & 42.9 \\
\hline Female & 60 & 57.1 \\
\hline Total & 140 & 100 \\
\hline \multicolumn{3}{|l|}{ Age } \\
\hline $21-30$ & 30 & 21.5 \\
\hline $31-40$ & 54 & 38.5 \\
\hline $41-50$ & 33 & 23.5 \\
\hline 51 and above & 23 & 16.4 \\
\hline Total & 140 & 100 \\
\hline \multicolumn{3}{|l|}{ Marital Status } \\
\hline Single & 19 & 13.6 \\
\hline Married & 115 & 82.1 \\
\hline Widowed & 1 & 0.7 \\
\hline Total & 140 & 100 \\
\hline \multicolumn{3}{|l|}{ Rank } \\
\hline Junior & 52 & 37.2 \\
\hline Senior & 72 & 51.4 \\
\hline Project & 16 & 11.4 \\
\hline Total & 140 & 100 \\
\hline Qualification(s) & & \\
\hline
\end{tabular}




\begin{tabular}{lcc}
\hline WASC & 12 & 8.6 \\
OND & 20 & 14.3 \\
Bachelors Degree & 70 & 50 \\
Master Degree & 38 & 27.1 \\
Total & 140 & 100 \\
\hline
\end{tabular}

Table 1 above shows the result of the descriptive statistics for the filtered demographic attributes of the respondents by their sex, age, marital status, rank and qualifications. Data on the table shows that a higher percentage $(57.1 \%)$ of the respondents were males. This implies that more males constitute the staff population of the Ministry of Environment. In analyzing the ages of the respondents, it was found that majority (38.5\%) of them fell between 31-40 years of age and 41-50 years (23.5\%) respectively, while just $4.5 \%$ were between $21-30$ years of age and $16.4 \%$ above 51 years. The result indicates that majority of the staff were in their middle ages and thus in their productive years.

The table further shows that the number of respondents that were married $(82.1 \%)$ was significantly higher than those that were single $(13.6 \%)$ and widowed $(0.7 \%)$ respectively. This is an indication that majority of the workforce of the Ministry of Environment are more likely to be married with families to cater for. In terms of rank, majority (51.4\%) of them belonged to the senior staff category, while $37.2 \%$ belonged to the junior staff category. The project staff constituted $11.4 \%$ of the respondents. Project staff is the term used to capture the newly recruited staff into the ministry who are expected to go through a probation period and are paid less than half the salary of the tenured staff.

Data on the qualifications of the respondents indicated that majority (50\%) of them possessed Bachelor's degree, while just $27.1 \%$ possessed Master's degree. This implies that the Ministry consists of staff with requisite qualifications and most likely accounts for the reason why majority of them belong to the senior staff category.

Table 2. Respondents' opinions on the motivational factors that affect their job performance (Numbers in brackets represent percentages)

\begin{tabular}{llllll}
\hline Variables & SA & A & U & D & SD \\
\hline $\begin{array}{l}\text { Conducive work environment enables me perform my job } \\
\text { better. }\end{array}$ & $69(49.3)$ & $42(30.0)$ & $15(10.7)$ & $12(8.6)$ & $2(1.4)$ \\
$\begin{array}{l}\text { Opportunity for autonomy, creativity and innovative } \\
\text { thinking provided encourages me to perform better. }\end{array}$ & $68(48.6)$ & $50(35.7)$ & $16(11.4)$ & $3(2.1)$ & $3(2.1)$ \\
$\begin{array}{l}\text { Reward through regular promotion motivates me to work } \\
\text { harder }\end{array}$ & $62(44.3)$ & $61(43.6)$ & $14(10.0)$ & $2(1.4)$ & $1(0.7)$ \\
$\begin{array}{l}\text { Opportunities for advancement and regular training enhance } \\
\text { my skill and improves my performance }\end{array}$ & $63(45.0)$ & $52(37.1)$ & $16(11.4)$ & $4(2.9)$ & $5(3.6)$ \\
$\begin{array}{l}\text { Available facilities are convenient and makes me work } \\
\text { faster }\end{array}$ & $59(42.1)$ & $48(34.3)$ & $17(12.1)$ & $10(7.1)$ & $6(4.3)$ \\
$\begin{array}{l}\text { Performance appraisal feedback from management enhances } \\
\text { my performance }\end{array}$ & $61(43.6)$ & $54(38.6)$ & $21(15.0)$ & $4(2.9)$ & - \\
\begin{tabular}{l} 
Regular salary and additional benefits \\
\hline
\end{tabular} & $72(51.4)$ & $50(35.7)$ & $4(2.8)$ & $8(5.7)$ & $6(4.2)$ \\
\hline
\end{tabular}

Key: SA = Strongly Agree, $\mathrm{A}=$ Agree, $\mathrm{U}=$ Undecided, $\quad \mathrm{D}=$ Disagree, $\mathrm{SD}=$ Strongly Disagree

Table 2 presents the respondents' opinions on the extent to which the available motivational factors within the ministry influence their job performance.Data on the table shows that of all the methods available for motivating staff "regular payment of salaries and provision of additional benefits (51.4\%)" mostly motivated the staff and enhanced their job performance. This finding supports the fact that money is important in motivating staff and that people should be given salaries and bonuses that reflect individual performances. The table further shows that most of the respondents $(49.3 \%)$ attributed improvement in their job performance to the conducive 
environment provided by the ministry. This result support studies (Batemam \& Snell, 2004) that affirm that a higher sense of achievement can be attained by giving workers freedom as well as an enriched work environment. Such environment promotes opportunity for learning, growth and freedom for workers to use their initiatives. This motivates employees to be committed to the organizations.

Data on the table shows that a sizeable number (48.6\%) of the respondents strongly agreed that the opportunity for autonomy, creativity and innovative thinking provided in the workplace influence their job performance. This was followed by opportunity for regular training (45\%); regular promotion $(44.3 \%)$, making performance appraisal feedback available to employees $(43.6 \%)$ and convenient work facilities $(42.1 \%)$. These result shows that opportunity for growth is a motivating factor and that workers demand growth opportunities from their employers. This has become increasingly necessary because organizations that provide these growth opportunities reap the benefits of having a motivated workforce with improved skills.

The results in the table however shows that not all needs are equally important in motivating workers; some provide much more powerful drive than others. Overall, this result has thus revealed that workers are mostly motivated to improve their performance through extrinsic reward by financial means, while the non-financial ones come after that.

Table 3. Respondents' opinions on the preferred strategies for enhancing job performance (Numbers in brackets represent percentages)

\begin{tabular}{|c|c|c|c|c|c|}
\hline Variables & SA & $\mathbf{A}$ & $\mathbf{U}$ & D & SD \\
\hline Granting project staff tenure & $78(55.7)$ & $49(35.0)$ & $17(8.6)$ & $1(0.7)$ & - \\
\hline $\begin{array}{l}\text { Provision of a robust and reliable retirement plan (Pension } \\
\text { scheme) }\end{array}$ & $75(53.6)$ & $52(37.1)$ & $12(8.6)$ & $1(0.7)$ & - \\
\hline $\begin{array}{l}\text { Recognizing and rewarding outstanding individual } \\
\text { performance }\end{array}$ & $76(54.3)$ & $52(37.1)$ & $7(5.0)$ & $4(2.9)$ & $1(0.7)$ \\
\hline $\begin{array}{l}\text { Enhanced salary with provision of welfare packages and } \\
\text { bonuses }\end{array}$ & $74(52.9)$ & $54(38.6)$ & $9(6.4)$ & $1(0.7)$ & $2(1.4)$ \\
\hline Provision of modern working equipments and facilities & $73(52.1)$ & $55(39.3)$ & $9(6.4)$ & $2(1.4)$ & $1(0.7)$ \\
\hline Promoting staff on merit & $74(52.9)$ & $50(35.7)$ & $9(6.4)$ & $7(5.0)$ & - \\
\hline Comprehensive and practical training programme & $70(50.0)$ & $60(42.9)$ & $6(4.3)$ & $4(2.9)$ & - \\
\hline
\end{tabular}

Key: SA = Strongly Agree, $\mathrm{A}=$ Agree, $\mathrm{U}=$ Undecided, $\quad \mathrm{D}=$ Disagree, $\mathrm{SD}=$ Strongly Disagree

Results in Table 3 above presents the views of the respondents on the preferred motivational strategies that can enhance their job performance. Data on the Table demonstrates that non-cash rewards play important role and are vital in motivating staff to perform better. It is not surprising therefore that a higher percentage $(55.7 \%)$ of the respondents strongly agreed that granting the project staff (this refers to those categories of staff on temporary appointment) tenure would significantly enhance their job performance. The reason for this may not be unconnected with the fact that having a tenured appointment gives staff a sense of belonging and commitment to the organization. Thus they are encouraged to give of their best and fully invest their time to the growth of the organisation. This result also implies that opportunity for growth is more of a motivating factor and that today's workers demand growth opportunities from their work place.

Result on the table further shows that a sizeable number $(54.3 \%)$ of the respondents strongly agreed and suggested that recognizing and rewarding outstanding performance would greatly motivate them to increase their job performance. This implies that staff of the Ministry of Environment which is typical of other employees in the Nigerian public sector place great emphasis and value on extrinsic factors as a means of being motivated to increase their job performance.

Furthermore (53.6\%) of the respondents strongly agreed and advocated for the provision of a robust and reliable retirement plan as a means of enhancing their performance. This is vital because a robust retirement plan is an effective strategy for satisfying the future needs of workers.

It is interesting to note that $52.9 \%$ of the respondents strongly agreed to the fact that enhanced salary with 
provision of welfare packages as well as promoting staff on merit (52.9\%) would enhance their job performance. The fact that the respondents perceived these two motivational strategies alike, may not be unconnected with the fact that promotion and enhancement of salary with welfare packages are extrinsic rewards linked to monetary terms. This finding confirms that of Herzberge et al. (1959) who affirmed that money in the form of pay or some other remuneration is the most obvious extrinsic rewards, this is because it provides the carrot that most people want. They noted that money is a highly tangible form of recognition and an effective means of helping people to work better, to feel that they are valued and to influence their retention.

Additional analysis on the table shows that $52.1 \%$ of the respondents strongly agreed that provision of modern working facilities and equipment would enhance their job performance. This result supports the views of Kusksus (2001) who noted that people are motivated to work better if they are provided the enabling environment with adequate working facilities. This according to him enriches their job as well as encourages and stimulates achievement.

Finally, 50\% strongly agreed that providing them with compressive and practical training programmes would motivate than to work better. This is because providing staff with opportunities for learning through the job enables them develop skills and competences to perform their jobs better.It should be noted that workers demand growth opportunities from their workplace and value new knowledge and skills acquired through training. Organizations that provide such growth opportunities reap the benefits of having a motivated workforce with improved skills.

\section{Conclusion}

This study examined the effects of motivation on the job performance of staff of the Lagos State Ministry of Environment in Nigeria. It also located those preferred strategies that motivate staff to enhance their performance. It is a commonly held belief that employees that are well motivated feel committed to the organization and perform their jobs better. This study affirmed this belief and specifically found that the key factors that motivate staff to perform their jobs better were mainly extrinsic than intrinsic. These include: regular salary and provision of welfare packages, conducive work environment, recognizing and rewarding outstanding performance, strengthening the retirement plant, just to mention a few. The result also suggested that not all these needs are equally important in motivating staff; rather some provide much more powerful drive than others. The organization in all of these must provide the context within which high levels of motivation can be achieved. Managers have a major role to play in order to accomplish this, by using their knowledge of motivational skills to get people to give of their best and to make good use of the existing motivational processes provided by the organization, while developing new ones.

It should however be noted that developing motivational systems which provide opportunities for both extrinsic and intrinsic reward to enhance performance is vital. Since well motivated workers perform best at work, this study advocates that organizations device, novel and workable strategies for motivating staff to achieve more.

\section{References}

Alderfer, C. (1972). Existence, relatedness and growth: Human needs in organizational settings. New York: Free Press.

Armstrong, U. (2006). A handbook of human resource management practice. Philadelphia: Kogan Ltd.

Bateman, T. S., \& Snell, S. A. (2004). Management: The new competitive landscape. New York: McGraw Hill.

Bloisi, W. (2007). An introduction to human resource management. Berkshire: McGraw-Hill.

Dinham, S., \&Scott, C. (1998). A three domain model of teacher and school executive career satisfaction. Journal of Educational Administration, 36(4), 362-378. https://doi.org/10.1108/09578239810211545

Evans, L. (1999). Managing to motivate: a guide for school teachers. London: Cassell.

Fielding, R. L. (2006). Employee motivational strategies. New York: Academic Press.

Glisson, C.V., \& Durick, M. (1988). Predictors of job satisfaction and organizational commitment in human service organizations. Administrative Quarterly, 33(1), 61-68. https://doi.org/10.2307/2392855

Herzberg, F., Mausner, B., \& Snyderman, B. (1959). The motivation to work. New York: John Wiley and sons.

Huczynski, A., \& Buchanan, D. (2007). Organizational behaviour: An introductory text. New Jersey: Prentice Hall.

Kuskus, F. (2001). Dimensions of employee satisfaction: A state university example. Development, 28(2), $399-430$. 
Lawal, A. (1993). Management in focus. Lagos: Abdal Publishers.

Lucy, F. J., \& Sheehan, B. A. (1997). Job satisfaction among academic staff: An International perspective. Higher Education, 34(3), 305-322. https://doi.org/10.1023/A:1003019822147

Luthans, F. (1952). Organizational behaviour. Boston. McGraw Hill.

Maslow, A. (1970). Motivation and personality. New York: Harper and Row.

Mitchell, T. (1982). Motivation: New directions for theory, research and practice. Academy of management review, 7(1), 80-88.

Mullins, L. (1996). Management and Organization (4th ed.). London: Pitman.

Obisi, C. (1996). Personnel management. Ibadan: Freeman Production.

Perry, J. L., \& Porters, L. R. (1982). The motivational bases of public service. Public Administration Review, 50, 367-373. https://doi.org/10.2307/976618

Scott, W. R. (2007). Organizations and organizing: rational, natural and open system perspectives. Stanford: Stanford University Press.

Ubeku, A. C. (1975). Personnel Management in Nigeria. Benin City: Ethiope Publishing Press.

\section{Copyrights}

Copyright for this article is retained by the author(s), with first publication rights granted to the journal.

This is an open-access article distributed under the terms and conditions of the Creative Commons Attribution license (http://creativecommons.org/licenses/by/4.0/). 